\title{
Gastric mucosal superoxide dismutases in Helicobacter pylori infection
}

\author{
J M Götz, C I van Kan, H W Verspaget, I Biemond, C B H W Lamers, R A Veenendaal
}

\begin{abstract}
Background-The mucosal pathology of Helicobacter pylori infection may in part be due to excessive production of reactive oxygen metabolites (ROMs) by phagocytes. The influence of $H$ pylori infection on mucosal superoxide dismutases, some major scavenger enzymes of ROM was investigated. In humans superoxidase dismutase is present in at least two forms that is, mitochondrial manganese (Mn)superoxide dismutase and cytoplasmic copper-zinc ( $\mathrm{CuZn})$-superoxide dismutase.

Methods-The amount and activity of both superoxide dismutases were measured, respectively by enzyme linked immunosorbent assay (ELISA) and spectrophotometrical enzyme activity assay, in gastric biopsy homogenates of patients with normal mucosa $(n=39)$ and in patients with $H$ pylori related gastritis $(n=71)$. Infection and gastritis were confirmed by a combination of culture, serology, and histology.
\end{abstract}

Results-The amount $(p<0.001)$ and activity $(p \leqslant 0.05)$ of $\mathrm{Mn}$-superoxide dismutase were increased by about twofold to threefold, whereas the amount and activity of CuZn-superoxide dismutase showed a slight decrease in gastric mucosa of patients with $H$ pylori gastritis, in both antrum and corpus, compared with normal mucosa of patients without $H$ pylori infection. Mn-superoxide dismutase concentrations in biopsy specimens of histologically normal corpus from patients with an inflamed antrum were significantly higher $(p<0.01)$ than that of patients with a histologically normal antrum.

Conclusion-H pylori infection has a differential effect on mitochondrial and cytoplasmic superoxide dismutase in the gastric mucosa, reflected by a pronounced increase in the cytokine inducible $\mathrm{Mn}$ superoxide dismutase and a marginal decrease in the constitutive CuZn-superoxide dismutase.

(Gut 1996; 38: 502-506)

Keywords: antioxidants, gastric mucosa, gastritis, Helicobacter pylori, reactive oxygen species, superoxide dismutase.

Helicobacter pylori is a small, curved or spiral shaped, Gram negative bacillus that lives in the human stomach and duodenum. ${ }^{1} H$ pylori infection is one of the most common bacterial infections worldwide and is the most common cause of gastritis. ${ }^{2}$ Almost $100 \%$ of people infected with $H$ pylori have gastritis, while over $90 \%$ of patients with gastritis have $H$ pylori infection. ${ }^{34}$ The prevalence of gastritis as well as $H$ pylori infection increases with advancing age. ${ }^{5}$ Furthermore, infection with $H$ pylori is the most important factor in peptic ulcer disease, and it is recognised as a pathogenic factor in gastric carcinogenesis. ${ }^{6-8}$ Normalisation of the gastric mucosa occurs as a result of successful eradication of $H$ pylori through antibacterial treatment. In the rare event of recurrent infection, there may be a relapse of the disease. ${ }^{9}$

Mucosal pathology related to $H$ pylori infection was at first explained by locally acting toxic factors such as cytotoxin, urease, and ammonia. There is growing evidence, however, that the mucosal damage is partly caused by attraction and activation of phagocytes, producing excessive amounts of reactive oxygen metabolites (ROMs). ${ }^{10}{ }^{11}$ In a previous study, for example, a positive correlation was found between ROM production and $H$ pylori status of patients. ${ }^{12}$ There was even a positive association between mucosal ROM production and quantitative histological and microbiological $H$ pylori assessments. ${ }^{13}$ These ROMs are highly toxic and can cause damage to all cellular components, including structural and regulatory proteins, carbohydrates, and DNA. ${ }^{14}$ Phagocytic cells produce large amounts of ROMs to facilitate killing of micro-organisms. ${ }^{15}$ Excessive ROM production seems to play a part in a number of diseases, including disorders of the gastrointestinal tract, as is shown in animal models and in some human studies. ${ }^{1617}$

Organisms possess a series of defence mechanisms, so called antioxidants, to terminate or reduce the toxicity of ROM reactions. ${ }^{18}$ One of the situations in which ROM production may exceed the natural defence system is that of phagocyte activation. Activated phagocytes produce superoxide anion $\left(\mathrm{O}_{\dot{i}}^{-}\right)$via a membrane bound NADPH oxidase. ${ }^{15}$ Myeloperoxidase, released from phagocytic granules of neutrophils, increases toxicity by catalysing the formation of hypochlorite. $H$ pylori can activate phagocytes in vitro with production of ROMs ${ }^{19-21}$ but $H$ pylor $i$ itself seems to be resistant to ROM toxicity because of either spatial isolation or to production of antioxidants. ${ }^{13}$

An enzyme that plays an important part in the defence mechanisms against reactive oxygen species is superoxide dismutase. ${ }^{22}$ Superoxide dismutase is an $\mathrm{O}_{\dot{2}}^{-}$scavenger and is known in humans to be present in at least two forms - that is, cytoplasmic copper/zinc
Correspondence to: Gastroenterology and Hepatology, University Hospital Leiden, Building 1 , C4-P, PO Box 9600,2300
RC Leiden, the Netherlands. Accepted for publication 23 October 1995 
$(\mathrm{CuZn})$-superoxide dismutase and mitochondrial manganese $(\mathrm{Mn})$-superoxide dismutase. Because Mn-superoxide dismutase is strategically located in the mitochondria, a site of considerable $\mathrm{O}_{\dot{2}}^{-}$production, it is probably an important first line of cellular defence against injury mediated by oxygen metabolites. Our group recently showed that intestinal inflammation in inflammatory bowel disease is accompanied by a dysfunction of superoxide dismutase, thus rendering the tissue vulnerable to ROM damage. ${ }^{23}$

The hypothesis for this study was that $H$ pylori infection might affect the amount or activity, or both, of gastric mucosal superoxide dismutases. Considering the excessive ROM production as a result of neutrophil activation, the amount and activity of gastric mucosal superoxide dismutase could modify potential mucosal injury by the bacteria. Thus, the aim of the study was to measure the amount and activity of $\mathrm{Mn}$-superoxide dismutase as well as $\mathrm{CuZn}$-superoxide dismutase in biopsy specimens of $H$ pylori associated inflamed mucosa and of normal gastric mucosa.

\section{Methods}

Biopsy material obtained through gastroscopy was initially available from 110 consecutive patients (65 male, 45 female, mean age 51 (13-80) years). Patients who used or had recently used proton pump inhibitors, corticosteroids, non-steroidal anti-inflammatory drugs (NSAIDs), bismuth compounds, sucralfate, or antibiotics were excluded. Use of $\mathrm{H}_{2}$ receptor antagonists was not considered a reason for exclusion. At endoscopy four biopsy specimens were obtained for histological examination, two from the antrum, 3-5 $\mathrm{cm}$ proximal to the pylorus, and two from the corpus, approximately $5 \mathrm{~cm}$ above the junction between antrum and corpus. These biopsy specimens were examined in accordance with the guidelines of the Sydney classification, by an experienced pathologist. A single specimen for culture was taken from the antrum and was processed as previously described. ${ }^{24}$ In 39 cases the stomach was histologically normal, while 48 patients had a pangastritis: both antrum and corpus showed histological signs of inflammation. In the other 23 cases only the antrum was inflamed.

A further two biopsy specimens of antrum and corpus were used for determination of $\mathrm{Mn}$-superoxide dismutase and $\mathrm{CuZn}$ superoxide dismutase concentration and activity. Homogenates were made by adding $100 \mu \mathrm{l}$ PBST $(0.05 \%$ TWEEN-20 in phosphate buffered saline) per mg biopsy material and homogenising on ice in a Potter S (B Braun). The protein concentration in the supernatant was determined by the Lowry assay. ${ }^{25}$

All cases of gastritis were caused by $H$ pylori. The presence of these bacteria was determined by a positive culture or histological identification, or both, and confirmed by specific IgG- $H$ pylori antibodies.
Enzyme linked immunosorbent assay for CuZnsuperoxide dismutase

The $\mathrm{CuZn}$-superoxide dismutase concentration in the tissue homogenates was determined by an ELISA. ${ }^{26}$ Each well of a flat bottom polystyrene microtitre plate (Dynatech Laboratories, USA; M129A) was coated with $100 \mu \mathrm{l}$ antibody solution $(10 \mu \mathrm{g} / \mathrm{ml}$ rabbit- $\alpha-$ $\mathrm{CuZn}$-superoxide dismutase in carbonate buffer, $\mathrm{pH} 9 \cdot 6$ ), overnight at $4^{\circ} \mathrm{C}$. A second coating followed with a $0.2 \%$ gelatin solution for one hour. The plates were washed and each homogenate, diluted 1:100 in PBST/gelatin $(0.05 \%$ TWEEN 20), was added to a well in duplicate. After two hours of incubation and washing, goat- $\alpha-\mathrm{CuZn}$-superoxide dismutase serum 1:2500 was added to the wells. The plates were incubated for 1.5 hours and washed again. Next, the wells were incubated for one hour with rabbit-goat-peroxidase (Dakopatts P449) 1:7500. Bound antibodies were detected using a solution of $40 \mathrm{mg}$ orthophenylenediamine (OPD) and $40 \mu \mathrm{l}$ $\mathrm{H}_{2} \mathrm{O}_{2}$ in $100 \mathrm{ml}$ citric acid/phosphate buffer, $\mathrm{pH} 5 \cdot 0$. The incubation time was 30 minutes for each well, the reaction being stopped with $50 \mu 12.5 \mathrm{M}$ sulphuric acid. The optical density was read at $492 \mathrm{~nm}$ on a Titertek Multiscan (Flow Laboratories, UK) plate reader. Finally, the $\mathrm{CuZn}$-superoxide dismutase concentration was calculated from a calibration curve based upon 10 standards between 1.25 and $40 \mathrm{ng} / \mathrm{ml}$ human recombinant (hr) $\mathrm{CuZn}$-superoxide dismutase and expressed per mg protein of the homogenate.

\section{ELISA for Mn-superoxide dismutase}

This procedure closely resembles the ELISA for $\mathrm{CuZn}$-superoxide dismutase. The microtitre plates were coated overnight with 10 $\mu \mathrm{g} / \mathrm{ml}$ rabbit- $\alpha-M n$-superoxide dismutase in carbonate buffer. The homogenates were diluted 1:50 in PBST and incubated for two hours. After washing, rabbit- $\alpha-\mathrm{Mn}$-superoxide dismutase-peroxidase 1:250 was added to each well. After one hour bound antibodies were detected as described for $\mathrm{CuZn}$-superoxide dismutase. The standard used in this assay was (hr) Mn-superoxide dismutase.

Human recombinant $\mathrm{Mn}$-superoxide dismutase and $\mathrm{CuZn}$-superoxide dismutase were kindly provided by Dr Z Yavin from the Kyriat Weizmann Institute, Rehovot, Israel. The antibodies against both human superoxide dismutases did not recognise $H$ pylori superoxide dismutase in western blotting nor did pure $H$ pylori extracts provide a signal in the ELISAs. Furthermore, $H$ pylori superoxide dismutase has recently been shown to be an iron containing superoxide dismutase. ${ }^{27}$

Superoxide dismutase activity measurement Superoxide dismutase activity was measured in 12 sets of normal tissue and 12 sets of inflamed tissue using the xanthine/xanthine oxidase/ cytochrome $c$ method. ${ }^{28}$ In the presence of xanthine, xanthine-oxidase produces $\mathrm{O}_{\dot{2}}^{-}$, which can be detected by its ability to reduce 
Figure 1: Mean concentration of Mn-superoxide dismutase ( $\mu \mathrm{g} / \mathrm{mg}$ protein (SEM)) in normal and inflamed antrum and corpus biopsy homogenates. Number of samples between brackets.

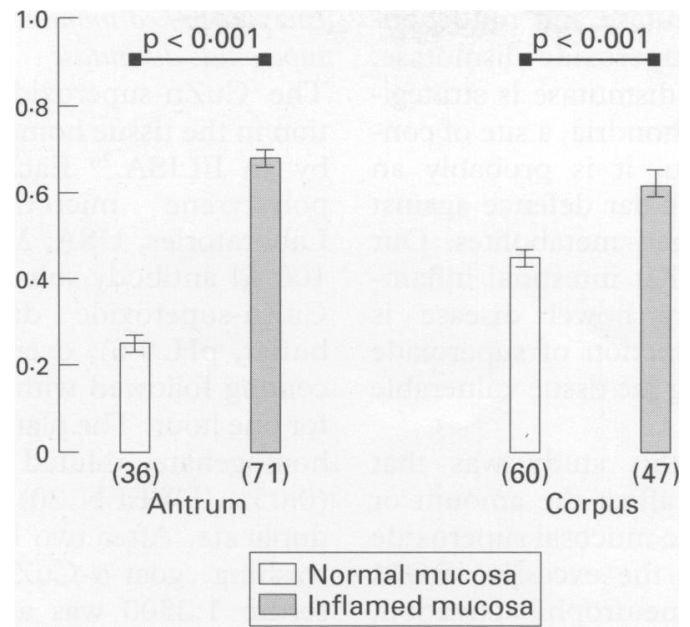

cytochrome c. This reduction will be inhibited by superoxide dismutase, through competition with cytochrome $c$ for the flux of $\mathrm{O}_{\dot{2}}^{-}$. In this assay, $80 \mu \mathrm{l}$ homogenate was added to $890 \mu \mathrm{l}$ phosphate buffer, $\mathrm{pH} 7 \cdot 8$. By adding $10 \mu \mathrm{l}$ xanthine ( $5 \mathrm{mg}$ in $6.57 \mathrm{ml} 0.05 \mathrm{M} \mathrm{KOH}$ ), xanthine-oxidase $(15 \mu \mathrm{l}$ in $435 \mu \mathrm{l}$ phosphate buffer), and cytochrome c (25 mg in $2.02 \mathrm{ml}$ phosphate buffer) the reaction started as described above. The reduction of cytochrome c was followed in a spectrophotometer at $\mathbf{5 5 0}$ $\mathrm{nm}$. To provide an estimate of total superoxide dismutase activity in each homogenate a calibration curve based upon five standards between 1.25 and $10 \mu \mathrm{g} / \mathrm{ml}$ superoxide dismutase was used. Mn-superoxide dismutase activity was determined using the same method, but in the presence of $1 \mathrm{mM}$ potassium cyanide, which inhibits $\mathrm{CuZn}$-superoxide dismutase for $\geqslant 90 \%$. CuZn-superoxide dismutase was thus estimated by subtraction of Mn-superoxide dismutase from total superoxide dismutase activity. The activity is expressed in units/mg protein, where one unit is the superoxide dismutase activity that causes $50 \%$ inhibition of the reaction rate in the absence of superoxide dismutase. For $\mathrm{CuZn}$ superoxide dismutase one unit corresponds with $180 \mathrm{ng}$ active (hr) CuZn-superoxide dismutase, while one unit Mn-superoxide dismutase corresponds with $225 \mathrm{ng}$ active (hr) Mn-superoxide dismutase.

Statistical analysis

The significance of the differences between the

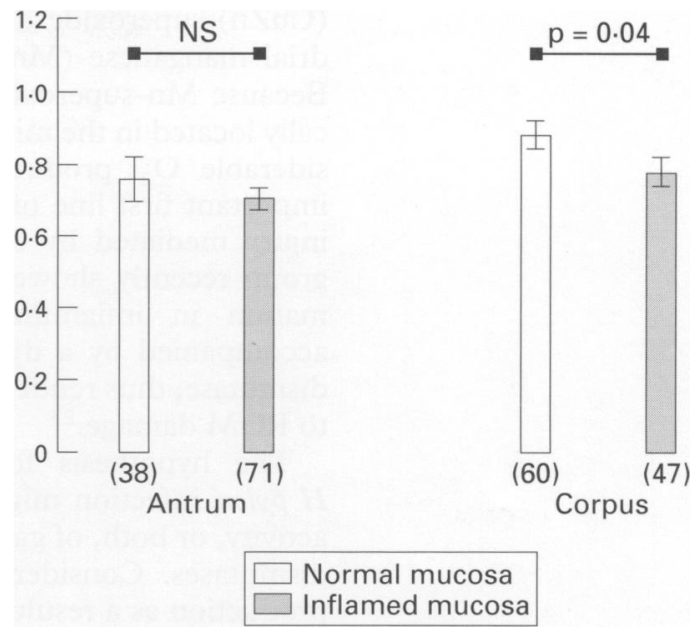

Figure 2: Mean concentration of $\mathrm{CuZn}$-superoxide dismutase ( $\mu \mathrm{g} / \mathrm{mg}$ protein (SEM)) in normal and inflamed antrum and corpus biopsy homogenates. Number of samples between brackets.

mean superoxide dismutase concentrations obtained through ELISA were determined with the unpaired Student's $t$ test with separate variance estimates if the standard deviations were significantly different according to the $F$ test. Where appropriate, the paired Student's $t$ test was also applied.

\section{Results}

Mn-superoxide dismutase and CuZn-superoxide dismutase concentrations

The mean Mn-superoxide dismutase and $\mathrm{CuZn}$-superoxide dismutase concentrations in normal as well as inflamed antrum and corpus biopsy homogenates are shown in Figs 1 and 2, respectively. The inflamed antrum contained significantly higher concentrations of $\mathrm{Mn}$ superoxide dismutase compared with normal antrum $(0.68(0.02) v 0.25(0.02)(\mu \mathrm{g} / \mathrm{mg}$ protein (SEM)), $\mathrm{p}<0.001)$. The same was true for corpus homogenates $(0.62(0.03) v 0.45(0.02)$, $\mathrm{p}<0.001)$. The CuZn-superoxide dismutase content in the inflamed corpus, however, was decreased in gastritis compared with normal corpus homogenates $(0.77(0.04) v 0.88(0.04)$, $\mathrm{p}=0.04)$. In antrum homogenates a similar, although not significant, trend was found in the $\mathrm{CuZn}$-superoxide dismutase concentration in inflamed and normal mucosa $(0.70(0.03) v$ $0.76(0.06), \mathrm{NS})$. The finding of a significant difference $(p<0.01)$ in the $M n$-superoxide

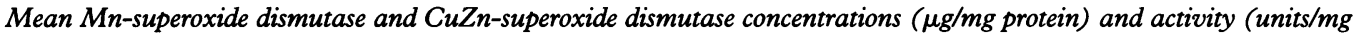
protein) in normal stomach and in pangastritis.

\begin{tabular}{|c|c|c|c|c|c|c|}
\hline & \multicolumn{3}{|l|}{ Normal mucosa } & \multicolumn{3}{|l|}{ Pangastritis } \\
\hline & Antrum & & Corpus & Antrum & & Corpus \\
\hline \multirow{2}{*}{$\begin{array}{l}\text { Concentration } \\
\text { Mn-superoxide dismutase (SEM) } \\
\text { p Value } \\
\text { Cu-Zn-superoxide dismutase (SEM) } \\
\text { p Value }\end{array}$} & $\begin{array}{l}(n=36) \\
0.25(0.02)\end{array}$ & \multirow{2}{*}{$\begin{array}{c}<0 \cdot 001 \\
\text { NS }\end{array}$} & $\begin{array}{l}(n=36) \\
0.41(0.03)\end{array}$ & $\begin{array}{l}(n=47) \\
0.69(0.03)\end{array}$ & \multirow[b]{2}{*}{$\begin{array}{l}\text { NS } \\
\text { NS }\end{array}$} & $\begin{array}{l}(n=47) \\
0.61(0.03)\end{array}$ \\
\hline & $0.80(0.06)$ & & $0.90(0.05)$ & $0.69(0.05)$ & & $0.77(0.04)$ \\
\hline \multirow{2}{*}{$\begin{array}{l}\text { Activity } \\
\text { Mn-superoxide dismutase (SEM) } \\
\text { p Value } \\
\text { Cu-Zn-superoxide dismutase (SEM) } \\
\text { p Value }\end{array}$} & $\begin{array}{l}(n=12) \\
0.69(0.46)\end{array}$ & \multirow[b]{2}{*}{$\begin{array}{c}\text { NS } \\
0.002\end{array}$} & $\begin{array}{l}(n=12) \\
0.75(0.30)\end{array}$ & $\begin{array}{l}(n=12) \\
2 \cdot 18(0 \cdot 49)\end{array}$ & \multirow[b]{2}{*}{$\begin{array}{l}\text { NS } \\
\text { NS }\end{array}$} & $\begin{array}{l}(n=12) \\
2.84(0.58)\end{array}$ \\
\hline & $9 \cdot 12(0.42)$ & & $7 \cdot 31(0 \cdot 31)$ & $7 \cdot 26(0 \cdot 70)$ & & $5.94(0.80)$ \\
\hline
\end{tabular}

Statistical analysis by the paired Student's $t$ test. 


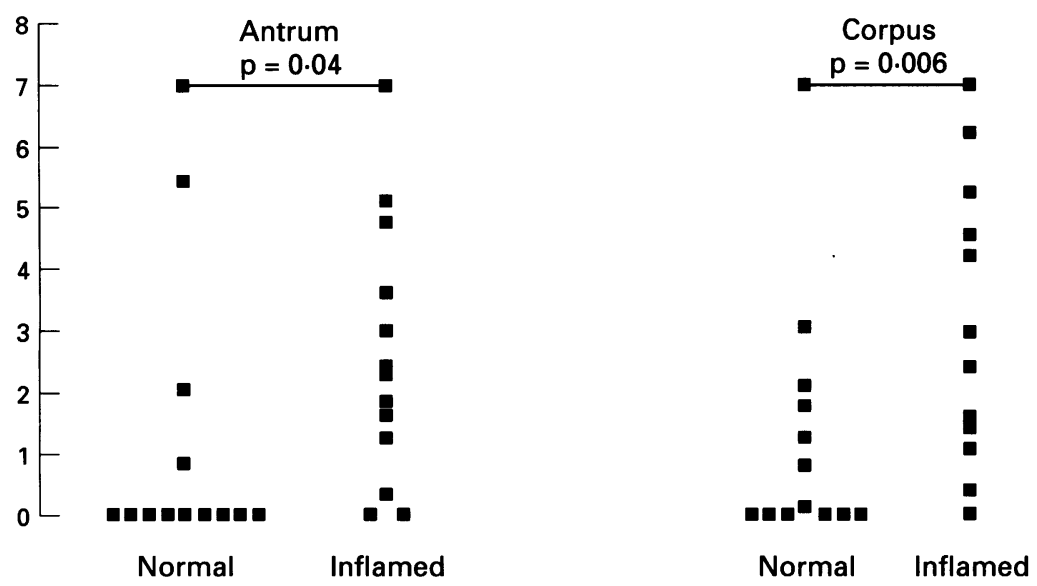

Figure 3: Individual activities of $\mathrm{Mn}$-superoxide dismutase (units/mg protein) in normal and inflamed antrum and corpus biopsy homogenates.

dismutase concentration within histologically normal corpus between those patients with a normal antrum and those with antral gastritis $(0.41(0.03) \quad(n=37) v 0.52(0.03) \quad(n=23)$, respectively) was of considerable interest.

A significantly higher $\mathrm{Mn}$-superoxide dismutase concentration was found in normal corpus mucosa specimens than in adjacent histologically normal antrum, within the same stomach. This difference was not found in the paired findings of inflamed corpus mucosa and adjacent inflamed antral mucosa, within the same stomach. No difference was found in $\mathrm{CuZn}$ superoxide dismutase concentrations in these groups. The Table shows these paired findings.

\section{Superoxide dismutase activity measurements}

Figures 3 and 4 show the mean superoxide dismutase activity values in normal and inflamed stomach. The Table shows the paired findings within normal stomach and inflamed stomach. In accordance with the results of the superoxide dismutase concentrations, the $\mathrm{Mn}$-superoxide dismutase activity was significantly higher in inflamed antral and corpus mucosa than in normal mucosa, while the activity of $\mathrm{CuZn}$ superoxide dismutase seemed to be decreased in the inflamed antrum and corpus, although this difference did not reach statistical significance in the corpus biopsy specimens.

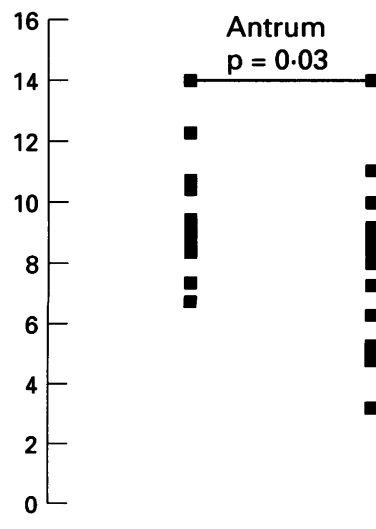

Normal

Inflamed

Normal

Inflamed

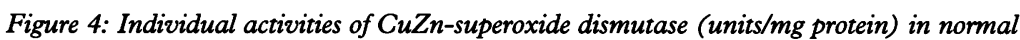
and inflamed antrum and corpus biopsy homogenates.

\section{Discussion}

In $H$ pylori infected antrum and corpus the amount and activity of Mn-superoxide dismutase were found to be significantly increased, thus contributing to protection against ROM damage. The concentration and activity of $\mathrm{CuZn}$-superoxide dismutase, however, were slightly decreased in the inflamed gastric mucosa.

These results are comparable to those reported by Verspaget et $a l^{23}$ who investigated the superoxide dismutase concentrations and activity values in the intestine of patients with inflammatory bowel disease. As in this study, they also found a large increase in the amount of Mn-superoxide dismutase in the inflamed tissue, although the $\mathrm{Mn}$-superoxide dismutase activity values in inflammatory bowel disease patients were only marginally increased. Furthermore, they also found $\mathrm{CuZn}$-superoxide dismutase values, concentration as well as activity, to be decreased in the inflamed tissue.

From this study it is not conclusive whether the effects on superoxide dismutase values are caused specifically by $H$ pylori or by gastric mucosal inflammation, as most patients with chronic active gastritis have an $H$ pylori infection. A direct interference of $H$ pylori, containing a distinct iron-superoxide dismutase, ${ }^{27}$ on the $\mathrm{Mn}$ - and $\mathrm{CuZn}$-superoxide dismutase determinations, however, was excluded by the absence of cross reactivity in the assays.

There are several possible explanations for the results obtained in this study. As for the increase in $\mathrm{Mn}$-superoxide dismutase values, it is known that Mn-superoxide dismutase, and not $\mathrm{CuZn}$-superoxide dismutase, can be induced by several cytokines including tumour necrosis factor $\alpha$ (TNF $\alpha)$, interferon $\gamma$ (IFN $\gamma$ ), and interleukin 1 (IL1). ${ }^{29-31}$. This is particularly relevant as mucosal cytokines, like TNF $\alpha$ and IL8, have been found to be increased because of infection with $H$ pylori. ${ }^{32} 33$ The fact that inflammation of the antrum causes an increase of the Mn-superoxide dismutase concentration in the corpus, even when the corpus shows no histological signs of $H$ pylori infection, might be caused by paracrine effects of gastric mucosal release of cytokines. The induction by cytokines seems paradoxical as $\mathrm{TNF} \alpha$ and IFN $\gamma$ also induce production of $\mathrm{O}_{\dot{2}}^{-}$during inflammation. The competition, however, may provide a mechanism for selective killing of infected or damaged cells during an immune response. As many viruses and some bacteria shut off synthesis of host proteins in infected cells, the production of superoxide dismutase might also be blocked. As a result, infected cells may be more vulnerable to damage by $\mathrm{O}_{\dot{2}}^{-} \cdot{ }^{34}$

The impairment of $\mathrm{CuZn}$-superoxide dismutase in the inflamed tissue might also be caused by inactivation through high local concentrations of free radicals or by a reduced local concentration of the enzyme, or both. ${ }^{34}$ Salo et al ${ }^{35}$ found that CuZn-superoxide dismutase is irreversibly inactivated by its own product $\mathrm{H}_{2} \mathrm{O}_{2}$. Exposure of red blood cells to $\mathrm{H}_{2} \mathrm{O}_{2}$ resulted in an inactivation of $\mathrm{CuZn}$ superoxide dismutase up to $50 \%$, while exposure to $\mathrm{O}_{\dot{2}}^{-}$and $\mathrm{H}_{2} \mathrm{O}_{2}$ together caused an 
inactivation of up to $75 \%$. Accompanying this loss of activity, the copper binding ability of the enzyme also diminishes with $\mathrm{H}_{2} \mathrm{O}_{2}$ exposure. As a result of these processes, CuZn-superoxide dismutase may become more susceptible to proteolysis and fragmentation.

Tissue injury by reactive oxygen metabolites has been implicated in the pathogenesis of peptic ulcer disease and gastric carcinoma, both $H$ pylori associated diseases. ${ }^{15}$

Although increased tissue concentrations of ROMs are not direct evidence for a pathogenic role, ${ }^{36}$ we showed for the first time that in $H$ pylori related gastritis a free radical scavenging system (Mn-superoxide dismutase) is changed, probably to compensate for the rate of radical generation.

Individual differences in this mechanism, either because of characteristics of $H$ pylori, such as cytotoxin or urease production, or because of host factors, such as diet, smoking, or primary dysfunction of the antioxidant system, might play a part in susceptibility to diseases like peptic ulcer disease or gastric carcinoma.

In conclusion, gastritis in the presence of $H$ pylori is characterised by a pronounced 'increase in the amount and activity of $\mathrm{Mn}$ superoxide dismutase, but a slight decrease in $\mathrm{CuZn}$-superoxide dismutase values. Further studies are needed to determine the exact contribution of changes in the superoxide dismutase values and $H$ pylor induced ROMs in patients with $H$ pylori associated gastritis, peptic ulcer disease, and gastric carcinoma, and the effect of treatment on superoxide dismutase values.

The authors would like to thank W van Duijn, G Kuiper, and $M$ A C Mieremet-Ooms for their technical assistance.

1 Warren JR, Marshall BJ. Unidentified curved bacilli on gastric epithelium in active chronic gastritis. Lancet 1983; i: 1273-5.

2 Taylor DN, Blaser MJ. The epidemiology of Helicobacter pylori infection. Epidemiol Rev 1991; 13: 42-59.

3 Rauws EAJ, Langenberg W, Houthoff HJ, Zanen HC Tytgat GNJ. Campylobacter pyloridis-associated chronic active antral gastritis: a prospective study of its prevalence and the effects of antibacterial and antiulcer treatment. Gastroenterology 1988; 94: 33-40.

4 Sobala GM, Axon ATR, Dixon MF. Morphology of chronic antral gastritis: relationship to age, Helicobacter pylori status, and peptic ulceration. Eur $\Im$ Gastroenterol Hepatol 1992; 4: 825-9.

5 Dooley CP, Cohen H, Fitzgibbons PL, Bauer M, Appleman MD, Perez-Perez GI, et al. Prevalence of Helicobacter pylori infection and histologic gastritis in asymptomatic persons. N Engl f Med 1989; 321: 1562-6.

$6 \mathrm{NIH}$ consensus development panel on Helicobacter pylori in peptic ulcer disease. Helicobacter pylori in peptic ulce disease. F $A M A$ 1994; 272: 65-9.

7 Correa P. Human gastric carcinogenesis: a multistep and multifactorial process. Cancer Res 1992; 52: 6735-40.

8 Parsonnet J, Hansen S, Rodriguez L, Gelb AB, Warnke RA, Jellum E, et al. Helicobacter pylori infection and gastric lymphoma. N Engl F Med 1994; 330: 1267-71.

9 Hentschel E, Brandstätter G, Dragosics B, Hirschl AM Nemec H, Schütze K, et al. Effect of ranitidine and amoxicillin plus metronidazole on the eradication of Helicobacter pylori and the recurrence of duodenal ulcer. HEngl $\mathcal{F}$ Med 1993; 328: 308-12.

10 Weiss SJ. Tissue destruction by neutrophils. $N$ Engl f Med 1989; 320: 365-76.

11 Halliwell B, Gutteridge JMC, Cross CE. Free radicals, antioxidants, and human disease: where are we now? $f$ Clin Lab Med 1992; 119: 598-620.

12 Davies GR, Simmonds NJ, Stevens TRJ, Sheaff MT,
Banatvala N, Laurenson IF, et al. Helicobacter pylor stimulates antral mucosal reactive oxygen metabolite production in vivo. Gut 1994; 35: 179-85.

13 Davies GR, Banatvala N, Collins CE, Sheaff MT, Abdi Y, Clements L, et al. Relationship between infective load of Helicobacter pylori and reactive oxygen metabolite production in antral mucosa. Scand $\mathcal{f}$ Gastroenterol 1994; 29: 419-24.

14 Cheeseman $\mathrm{KH}$, Slater TF. An introduction to free radical biochemistry. Br Med Bull 1993; 49: 481-93.

15 Davies GR, Rampton DS. Helicobacter pylori, free radicals and gastroduodenal disease. Eur $\mathcal{F}$ Gastroenterol Hepatol 1994; 6: $1-10$.

16 Niida H, Okada M, Takeuchi K, Okabe S. A new model of duodenal ulcers induced in rats by diethyldithiocarbamate, a superoxide dismutase inhibitor. Scand $\mathcal{f}$ Gastroenterol 1989; 162 (suppl): 116-9.

17 Naito Y, Yoshikawa T, Ando T, Kishi A, Ueda S, Oyamada $\mathrm{H}$, et al. Changes in superoxide dismutase activity in the gastric mucosa of peptic ulcer patients. $\mathcal{F}$ Clin Gastroenterol 1992; 14 (suppl 1): S131-4.

18 Smith SM, Kvietys PR. Gastric ulcers: role of oxygen radicals. Crit Care Med 1988; 16: 892-8.

19 Mooney C, Keenan J, Munster D, Wilson I, Allardyce R, Bagshaw P, et al. Neutrophil activation by Helicobacter pylori. Gut 1991; 32: 853-7.

20 Mai UEH, Perez-Perez GI, Wahl LM, Wahl SM, Blaser MJ, Smith PD. Soluble surface proteins from Helicobacter pylori activate monocytes/macrophages by Helicobacter pylori activate monocytes/macrophages by 1991; 87: 894-900.

21 Rautelin H, Blomberg B, Fredlund H, Järnerot G, Danielsson D. Incidence of Helicobacter pylori strains activating neutrophils in patients with peptic ulcer disease. Gut 1993; 34: 599-603.

22 Ogino K, Oka S, Okazaki Y, Takemoto T. Gastric mucosal protection and superoxide dismutase. $\mathcal{f}$ Clin Gastroenterol 1988; 10 (suppl 1): S129-32.

23 Verspaget HW, van Ierssel AJHM, van Duijn W, MieremetOoms MAC, van Hogezand RA, Griffioen G, et al. Dysfunctional superoxide dismutases in inflamed intestine of patients with inflammatory bowel disease tine of patients with inflammatory

24 Veenendaal RA, Lichtendahl-Bernards AT, Peña AS, Endtz $\mathrm{HPh}$, van Boven CPA, Lamers CBHW. Effect of transport medium and transportation time on culture of Helicobacter pylori from gastric biopsy specimens. $\mathcal{F}$ Clin Pathol 1993; 46: 561-3.

25 Lowry OH, Rosebrough NJ, Farr AL, Randall RJ. Protein measurement with the folin phenol reagent. $\mathcal{F}$ Biol Chem 1951; 193: 265-75.

26 Verspaget HW, Peña AS, Weterman IT, Lamers CBHW. Diminished neutrophil function in Crohn's disease and ulcerative colitis identified by decreased oxidative metabolism and low superoxide dismutase content. Gut 1988; 29: 223-8.

27 Spiegelhalder C, Gerstenecker B, Kersten A, Schiltz E, Kist $M$. Purification of Helicobacter pylori superoxide dismutase and cloning and sequencing of the gene. Infect Immun 1993; 61: 5315-25.

28 McCord JM, Fridovich I. Superoxide dismutase. An enzymic function for erythrocuprein (hemocuprein) f Biol Chem 1969; 244: 6049-55.

29 Warner BB, Burhans MS, Clark JC, Wispé JR. Tumor necrosis factor- $\alpha$ increases Mn-SOD expression: protection against oxidant injury. Am $\mathcal{f}$ Physiol 1991; 260 L296-301.

30 Visner GA, Dougall WC, Wilson JM, Burr IA, Nick HS. Regulation of manganese superoxide dismutase by lipopolysaccharide, interleukin-1, and tumor necrosis factor. $¥ \mathrm{Biol}$ Chem 1990; 265: 2856-64

31 Harris CA, Derbin KS, Hunte-McDonough B, Krauss MR Chen KT, Smith DM, et al. Manganese superoxide dismutase is induced by IFN- $\gamma$ in multiple cell types. dismutase is induced by IFN-

32 Crabtree JE, Shallcross TM, Heatley RV, Wyatt JI. Mucosal tumour necrosis factor $\alpha$ and interleukin- 6 in patients with Helicobacter pylori associated gastritis. Gut 1991 32: 1473-7.

33 Crabtree JE, Peichl P, Wyatt JI, Stachl U, Lindley IJD. Gastric interleukin-8 and IgA IL-8 autoantibodies in Helicobacter pylori infection. Scand f Immunol 1993; 37: 65-7.

34 Mulder TPJ, Verspaget HW, Janssens AR, de Bruin PAF, Lamers CBHW. Decrease in two intestinal copper/zinc containing proteins with antioxidant function in inflammatory bowel disease. Gut 1991; 32: 1146-50

35 Salo DC, Pacifici RE, Lin SW, Giulivi C, Davies KJA. Superoxide dismutase undergoes proteolysis and frag-
mentation following oxidative modification and inactivamentation following oxidative modifica
tion. $\mathcal{F}$ Biol Chem 1990; 265: 11919-27.

36 Graham DY. Polymorphonuclear leucocytes traffic into the gastric mucosa and through the gastric mucosal barrier in $\mathrm{H}$ pylori infection: is that bad? In: Hunt RH, Tytgat GNJ, eds. Helicobacter pylori: Basic mechanisms to clinical cure. Dordrecht: Kluwer Academic, 1994: 214-21. 